\title{
Chapter 11. USPB/Snack Food Association Potato Variety Trial, 20061
}

\section{M. Hutchinson and Doug Gergela ${ }^{2}$}

\begin{tabular}{|c|c|}
\hline \multicolumn{2}{|c|}{$\begin{array}{l}\text { A goal of the Snack Food Association trial is to identify a short-season processing potato variety with better } \\
\text { production and quality characteristics than placeAtlantic, the current standard. Chip quality was determined by } \\
\text { personnel at Utz Quality Foods. } \\
\text { Planting Information }\end{array}$} \\
\hline Planting Site & PSREU - Hastings Farm, Hastings, FL \\
\hline Planting Date & February 1, 2006 \\
\hline Harvest Date & May 22,2006 \\
\hline Season Length & 110 days \\
\hline Fertilizer Program & preplant, $100-43-86 \mathrm{lb} / \mathrm{A}$; sidedress, $65-0-56 \mathrm{lb} / \mathrm{A}$ (2 appl.) \\
\hline Irrigation Program & seepage \\
\hline \multicolumn{2}{|l|}{ Experimental Design } \\
\hline Number of Varieties & 3 (Standard: Atlantic) \\
\hline Number of Clones & 9 \\
\hline Within Row Spacing & Approx. 8 in $(20.3 \mathrm{~cm})$ \\
\hline Between Row Spacing & 40 in $(102 \mathrm{~cm})$ \\
\hline Replications & 1 \\
\hline Plot Size & $\begin{array}{l}\text { Single } 250 \mathrm{ft} \text { row }(76.2 \mathrm{~m}) \text { planted for each variety. Four, } 20 \mathrm{ft}(6.1 \mathrm{~m}) \text { plots } \\
\text { harvested from each row to determine production and quality statistics. }\end{array}$ \\
\hline \multicolumn{2}{|l|}{ Production Statistics } \\
\hline Early Vigor Ratings & 41 days after planting. \\
\hline Highest Total Yield & MSJ316-A (454 cwt/acre or $50.9 \mathrm{MT} / \mathrm{ha})$ \\
\hline Highest Marketable Yield & NY132 (394 cwt/acre or $44.1 \mathrm{MT} / \mathrm{ha})$ \\
\hline Highest Specific Gravity & Atlantic, AF2211-9, and MSJ147-1 (1.090) \\
\hline
\end{tabular}

1. This document is HS1095, one of a series of the Horticultural Sciences Department, Florida Cooperative Extension Service, Institute of Food and Agricultural Sciences, University of Florida. Original publication date May, 2007. Visit the EDIS Web Site at http://edis.ifas.ufl.edu.

2. Chad M. Hutchinson, Associate Professor, Doug Gergela, Sr. Biological Scientist, Horticurtural Sciences Department, Cooperative Extension Service, Insitute of Food and Agricultural Sciences, University of Florida, Gainesville, 32611.

The use of trade names in this publication is solely for the purpose of providing specific information. UF/IFAS does not guarantee or warranty the products named, and references to them in this publication does not signify our approval to the exclusion of other products of suitable composition. All chemicals should be used in accordance with directions on the manufacturer's label. Use pesticides safely. Read and follow directions on the manufacturer's label.

The Institute of Food and Agricultural Sciences (IFAS) is an Equal Opportunity Institution authorized to provide research, educational information and other services only to individuals and institutions that function with non-discrimination with respect to race, creed, color, religion, age, disability, sex, sexual orientation, marital status, national origin, political opinions or affiliations. U.S. Department of Agriculture, Cooperative Extension Service, University of Florida, IFAS, Florida A. \& M. University Cooperative Extension Program, and Boards of County Commissioners Cooperating. Larry Arrington, Dean 


$$
\text { 䐓 }
$$




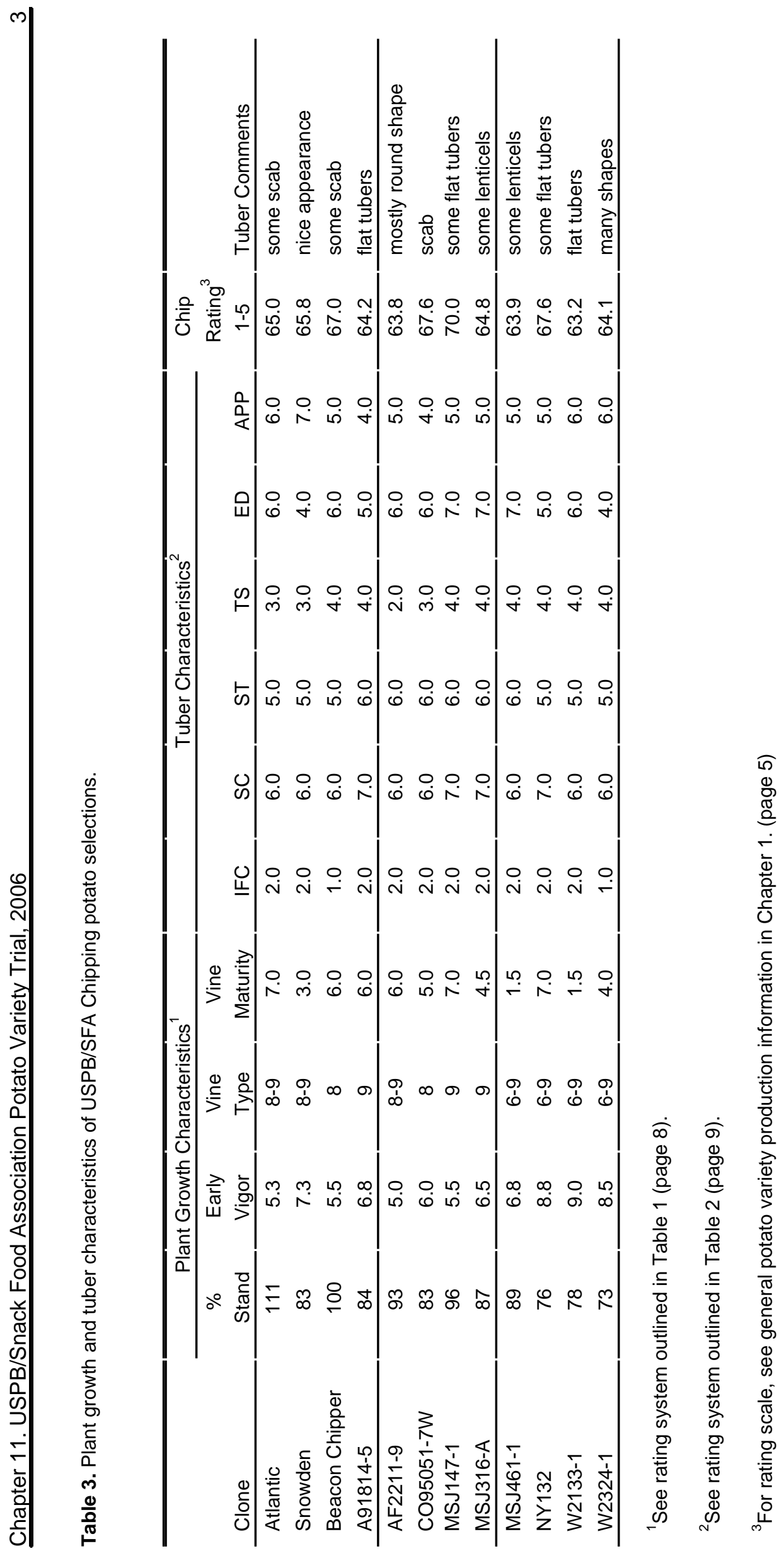




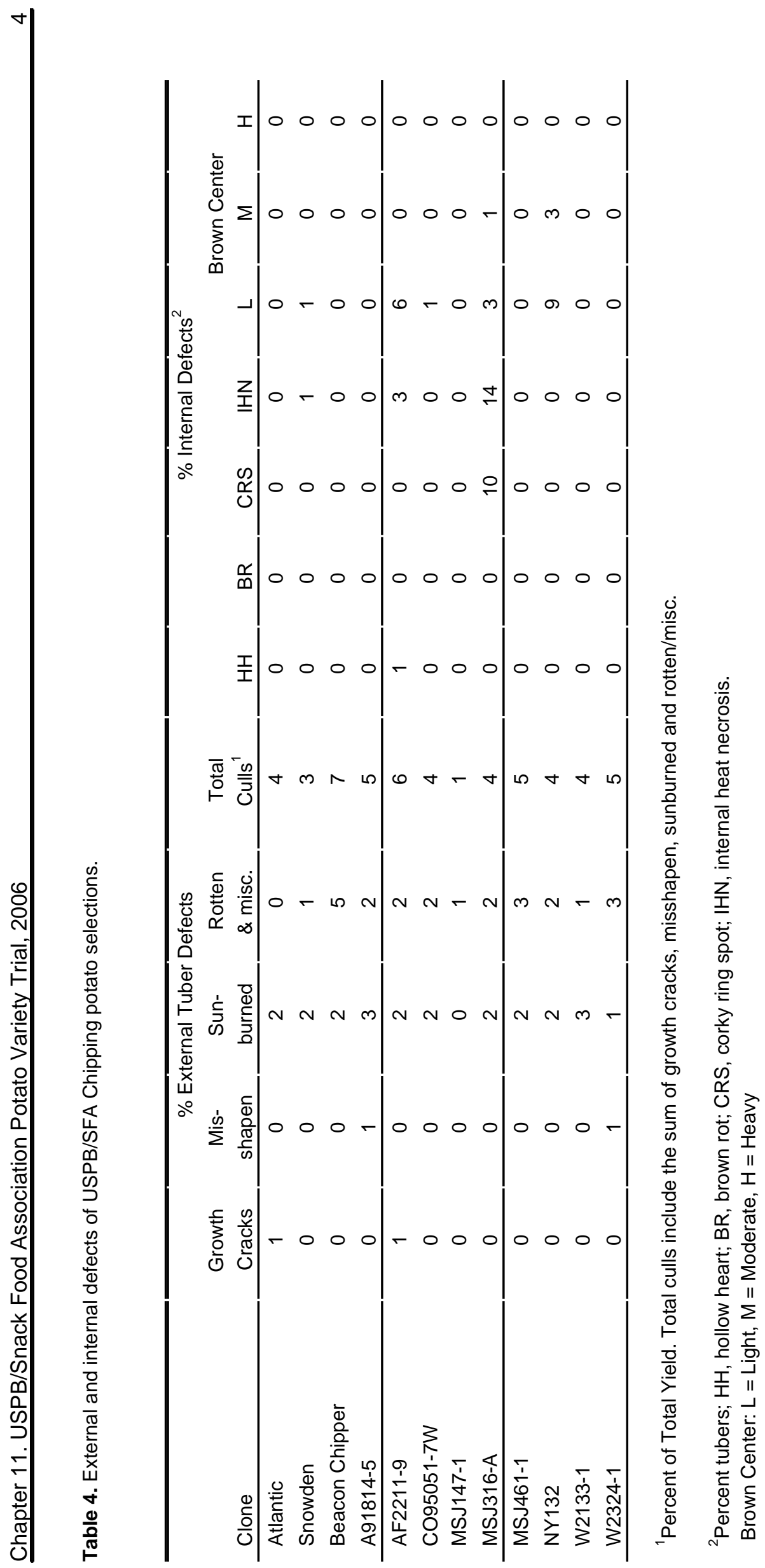

